\title{
Effect of pyroligneous acids on urease inhibition
}

\author{
Hyun Jun Park ${ }^{1}$ Jin Hee Park²

\section{요소분해 저해에 미치는 목초액의 영향 평가}

\author{
박현준 ${ }^{1} \cdot$ 박진희 $^{2}$
}

Received: 23 May 2017 / Accepted: 11 June 2017 / Published Online: 30 June 2017

(C) The Korean Society for Applied Biological Chemistry 2017

\begin{abstract}
This study was conducted to investigate the effect of pyroligneous acids on urea hydrolysis for the purpose of inhibiting ammonia volatilization during urea fertilizer application. Different types of synthetic urease inhibitors have been searched and developed, but their use is limited due to varying inhibition effects on soil urease, and environmental problems. In this study, the effect of pyroligneous acids, a natural substance, on urea hydrolysis in soil was evaluated by analyzing inhibition of urease activity. Pyroligneous acids inhibited plant urease and microbial urease activity, as well as soil urease with various urease complex. In addition, pyroligneous acids exhibited non-competitive urease inhibition effect through urease kinetics and inhibited urea hydrolysis in the soil. This study showed that pyroligneous acids treatment with urea fertilizer decreases the loss of urea fertilizer, improves the efficiency of nitrogen application on plant and reduces the amount of nitrogen fertilizers applied in soil.
\end{abstract}

Keywords Non-competitive inhibition · Pyroligneous acids · Soil - Urea hydrolysis · Urease

Jin Hee Park $(\bowtie)$

E-mail: pjinh@cbnu.ac.kr

${ }^{1}$ Soil research institute, Purumbio Co. Ltd., Damyang, Jeonnam 57312, Republic of Korea

${ }^{2}$ School of Crop Science and Agricultural Chemistry, Chungbuk National University, Cheongju, Chungbuk, 28644, Republic of Korea

This is an Open Access article distributed under the terms of the Creative Commons Attribution Non-Commercial License (http://creativecommons. org/licenses/by-nc/3.0/) which permits unrestricted non-commercial use, distribution, and reproduction in any medium, provided the original work is properly cited.

\section{서 론}

최근 양분총량제 도입을 앞두고 양분수지(양분의 투입과 소모 간 차이)에 대한 관심이 높아지고 있으나, 그간 우리나라는 $\mathrm{OECD}$ 국가 중에서 질소성분 기준 가장 많은 양분 투입국으로 알려져 있다. 이미 $\operatorname{Lim}(1996)$ 은 화학비료를 적절하게 관리하고 사용하여 과다 투입된 양분이 없다면 토양과 수질 오염이 없는 진정한 친환경 농업을 할 수 있으며 화학비료를 사용하지 않고 유기성 부산물비료에만 의존하는 지금의 환경농업은 농업 수량 감소뿐 아니라 토양의 질 변화, 불량한 비료에 의한 토양오염 및 농산물의 안정성, 외인성 잡초 및 병원균의 도래 등을 초래 할 수 있어 토양 별, 작물생육 별 최적, 최소의 사용과 환경 친 화적인 비료의 개발이 필요하다고 하였다.

이번 연구는 이러한 시대적 요구에 부응하여 우리나라에서 가장 많이 사용하고 있는 요소비료의 효율성을 높이고자 하는 것이다. 요소비료는 $45 \%$ 이상의 질소성분으로 질소비료 중 가 장 질소성분이 높지만 살포시 각종 식물 및 토양미생물에서 분 비되는 요소 가수분해 효소인 urease에 의해 가수분해되어 탄 산암모늄을 거쳐 이산화탄소와 암모니아로 분해된다. 특히 첨가 된 질소 중 약 $40 \%$ 가 특정 환경 조건하에서 $\mathrm{NH}_{3}$ 로 손실되며 합성 비료에서 약 $10-14 \%$ 의 질소가 휘발을 통해 손실된다. 이 와 같은 질소의 손실은 경제적으로 문제가 될 뿐만 아니라 $\mathrm{N}_{2} \mathrm{O}$ 의 발생으로 이어져 온실효과를 일으키기도 한다(Pan 등, 2016). 토양에서 암모니아의 방출은 부영양화를 일으킬 수 있으며 작 물의 발아와 성장에 대하여 저해 작용을 유발하며 아질산태와 암모니아에 의한 독성을 나타내게 한다(Esteban 등, 2016).

따라서 토양에서 암모니아의 휘산을 감소시키기 위해 적절한 시기에 적절한 양의 질소 비료 사용, 관개수 조절 등 여러 가 지 방안들이 연구되었으며 완효성 질소질 비료에 대한 연구도 진행되고 있다. 완효성 질소질 비료는 속효성 질소질 비료와는 달리 암모니아태 질소, 질산태 질소로의 분해가 늦은 것이 특 징으로 작물 생육 후기까지 작물요구에 충분한 양분을 공급하 
고 환경에 유해한 영향을 감소시킬 수 있다(Shaviv 2001).

최근까지 요소 시비 후 urea의 가수분해를 조절하여 토양에 서 질소가 유출되는 것을 막기 위해 urease 활성을 저해하기 위 한 연구가 활발히 수행되고 있다. 토양 중 urease는 부식물 혹 은 토양 교질물에 의하여 보호되어 그 활성을 나타내기에 안전 한 형태로 존재하는 것으로 알려져 있다(Bai 등, 2014). 또한 토양에서 urease 활성은 환경적 조건에 의해 영항을 받는데 $\mathrm{pH}$, 온도, 수분함량, 유기물 함량, 총 질소 함량, $\mathrm{CEC}$, 점토와 미사 함량 등에 의해 영향을 받는다(Byrnes과 Freney 1995). 토양에 시용되는 다양한 토양 개량제, 비료, 농약류, 중금속 등에 의해 서도 그 활성이 증가 또는 억제 되는 것으로 알려져 있다(Kiss 와 Stefan 2013). 현재까지 개발된 urease 활성 저해제로는 $p$ benzoquinone류, hydroxyquinone, heterocyclic sulfur 화합물류, substituted urea herbicide 류, phosphoroamide류 등이 있다(Xu 등, 2000; Zaborska 등, 2002; Krajewska와 Zaborska 2007; Dominguez 등, 2008; McKenzie 등, 2010). 또한 결명, 쑥, 목 재타르 추출물 등 천연물에서 urease 활성 저해제를 찾고자 하 는 연구도 있었다( $\mathrm{Lim}$ 등, $1998 ; \mathrm{Kim}$ 등, 2000). 하지만 기존 에 수많은 요소분해 저해제 중 고독성 화학합성물은 사용이 금 지되었으며 천연물로서 사용되는 요소분해 저해제는 아직까지 없는 실정이다.

현재 세계적으로 가장 안정되게 사용되는 urease inhibitor는 $\mathrm{N}-(\mathrm{n}$-butyl) thiophosphoroic triamide (NBPT)로 주로 외국에서 대단위 농장규모에서 사용되고 있으며 요소중량 대비 약 $0.045 \%$ 의 낮은 농도에서도 사용가능하나 우리나라에서는 아직까지 사 용된 실적이 없다. 따라서 본 연구에서는 목초액의 요소분해 억 제 효과를 평가하여 NBPT와 같이 실제적으로 농업에 사용할 수 있는 친환경 천연 urease inhibitor 개발에 보탬이 되고자 한 다. 목초액의 urease 억제효과를 발표한 바 있으나(Kim 등, 2000) 암모니아 분석을 Kjeldahl 증류법으로 하였기 때문에 정 확하나 많은 시간과 노력이 소모되어 재검증과 목초액 내 성분 을 탐색할 때 어려움이 있었다.

이번 연구에서는 indophenol blue법을 활용하여 정확하면서도 쉽고 빠른 측정방법을 확립하여 urease 저해효과를 갖는 목초 액 내 성분뿐만 아니라 다양한 천연물질을 탐색하는데 도움이 되고자 하였다. 요소비료와 함께 목초액을 사용하면 암모니아 휘산으로 인한 손실을 줄일 수 있어 식물에 공급되는 질소의 효율을 증진시킴과 동시에 토양에 공급되는 질소비료의 총량을 절감하여 친환경 농업에 도움이 될 것으로 판단된다. 본 연구 에서는 천연물질인 목초액의 토양 중 urease 활성 저해, 반응속 도 측정 및 저해 기작과 토양 내 요소가수분해 억제에 대한 효 과를 종합적으로 평가하였다.

\section{재료 및 방법}

\section{목초액 특성 분석}

목초액은 강원목초액(강원도 영월군 북면 강구길 50-23)을 사용 하였으며 상온 보관하였다. 목초액의 $\mathrm{pH}$ 는 $\mathrm{pH}$ meter (Orion)로 측정하였고, 증류 잔사물은 일정량 $(1 \mathrm{~L})$ 을 취한 후 감압증류하 고 냉동건조하여 남은 무게로 측정하였다. 전 질소함량과 암모 늄태 질소 및 질산태 질소는 Kjeldahl법으로 분석하였다. 증류
잔사물은 urease 활성 평가를 위해 $\mathrm{MeOH}$ 에 녹여 농도 10,000 $\mathrm{mg} / \mathrm{L}$ 로 맞춘 후 냉장 보관하였다.

\section{토양의 물리 - 화학적 특성 분석}

토양은 하우스 내 밭토양(경기도 광주시 오포읍 양벌리 64-1)에 서 표토 $1 \mathrm{~cm}$ 를 제거한 후 오거를 이용하여 깊이 $1-15 \mathrm{~cm}$ 인 층 을 채취하였으며 음건한 후 상온 보관하였고 토양 urease 활성 측정 전 수분함량을 $20 \%(\mathrm{~W} / \mathrm{W})$ 로 맞춘 뒤 $35^{\circ} \mathrm{C}$ 에서 1 일 동안 배양 후 사용하였다. 토양의 $\mathrm{pH}$ 와 $\mathrm{EC}$ 는 토양 $10 \mathrm{~g}$ 에 증류수 (1:5)를 넣어 1 시간 교반 후 $\mathrm{pH}$ meter와 $\mathrm{EC}$ meter로 측정하였 고(McLean 1982), CEC는 ammonium acetate법(Rhoades 1982) 으로 분석하였다. 유기물 함량은 회화법으로 분석하였으며, 유 효인산은 Bray No. 1법(Bray와 Kurtz 1945)으로 분석하였다. 총질소는 Kjeldahl 분해법의 변법으로 salicylic acid-thiosulfate 황산법(Bremner와 Mulvaney 1982)으로 분해 정량하였고, 암모 늄태 질소와 질산태 질소는 $2 \mathrm{M} \mathrm{KCl}$ 추출 후 $\mathrm{Kjeldahl} \mathrm{증류법}$ 으로(Bremner와 Keeney 1965) 분석하였다. CEC 및 $\mathrm{Ca}, \mathrm{Mg}$, $\mathrm{K}, \mathrm{Na}$ 함량은 $1 \mathrm{~N}$ ammonium acetate로 추출 후 $\mathrm{ICP}$ 로 분석 하였고(Reeuwijk 2002), 토성분석은 피펫법(Green 1981)으로 분 석하였다.

\section{Jack bean과 Bacillus urease 활성에 미치는 목초액의 영향} 목초액이 식물 urease와 미생물 urease 활성에 미치는 영향을 알아보기 위하여 jack bean urease $(440,000 \mathrm{unit} / \mathrm{g}$, Sigma)와 Bacillus pasteurii urease (220,000 unit/g, Sigma)를 식물과 미 생물의 대표적 urease로 사용하였다. Urease 활성측정은 Tabatabai 와 Bremner(1972), Mobley와 Hausinger(1989), Keeney와 Nelson (1982)의 방법을 수정하여 사용하였다. $100 \mathrm{mM}$ phosphate buffer (pH 7.0)에 $10 \mathrm{mM}$ EDTA 와 $20 \%$ glycerin을 첨가한 phosphate-EDTA buffer (PEB)용액에 요소가수분해효소(Jack bean urease, Bacillus urease)를 $30 \mathrm{unit} / \mathrm{mL}$ 가 되도록 각각 녹 여 준비하였다. 요소가수분해 후 발생한 암모니아의 농도차이로 활성을 분석하였는데 암모니아의 농도는 indophenol blue법의 변법(Keeney와 Nelson 1982)을 이용하여 분석하였다. 증류수 $465 \mu \mathrm{L}, 10$ 배 희석한 PEB $60 \mu \mathrm{L}$, Urease $5 \mu \mathrm{L}, 160 \mathrm{mM}$ urea$\mathrm{N} 40 \mu \mathrm{L}$, 목초희석액을 증류잔사물 기준 농도 별 $(100,1,000$, $10,000 \mathrm{mg} / \mathrm{L}$ )로 $30 \mu \mathrm{L}$ 를 넣고 $35^{\circ} \mathrm{C}$ 에서 3 분간 반응시켰다. 이 중 $150 \mu \mathrm{L}$ 를 취해 phenol-nitroprusside $300 \mu \mathrm{L}$ 와 $\mathrm{NaOH}$-hypochlorite $300 \mu \mathrm{L}$ 를 넣은 후 $50{ }^{\circ} \mathrm{C}$ 수조에서 30 분간 발색시키고 $630 \mathrm{~nm}$ 에서 흡광도를 측정하였다. 암모니아 농도는 표준물질과 흡광도 의 검량선을 이용하여 환산하였으며, urease 활성 저해도 $(\%)$ 는 control의 암모니아 농도를 저해도 $0 \%$ 로 기준하여 그 차이로 계 산하였다. Urease를 넣지 않고 반응시킨 측정값을 각 처리별로 제외하여 목초액 내 암모니아 농도의 영향을 배제하였으며, control은 목초액 대신 $\mathrm{MeOH}$ 을 처리하는 것으로 하였다.

\section{토양 urease 활성에 미치는 목초액의 영향}

토양 urease 활성 측정은 음건 후 수분함량을 $20 \%(\mathrm{~W} / \mathrm{W})$ 로 맞추고 $35^{\circ} \mathrm{C}$ 에서 하루 배양한 토양 $2 \mathrm{~g}$ 에 toluene $80 \mu \mathrm{L}$ 를 첨 가 후 $\mathrm{PEB}(\mathrm{pH} 7.0) 4 \mathrm{~mL}$ 를 더하여 효소액을 준비하였다. 요 소농도와 배양온도, 처리조건은 jack bean과 Bacillus urease 활 성 측정방법과 같고 3 시간 동안 배양하였다. 반응 후 stop 
reagent로 $\mathrm{Ag}_{2} \mathrm{SO}_{4}(3 \mathrm{mg} / \mathrm{mL})$ 를 $2 \mathrm{~mL}$ 첨가하여 반응을 종결시 킨 후 $2 \mathrm{M} \mathrm{KCl}$ 을 $20 \mathrm{~mL}$ 넣어 30 분간 진탕 후 No. 2 여과지 에 여과하였다. 증류수 $400 \mu \mathrm{L}$ 에 여과한 토양 추출액 $100 \mu \mathrm{L}$ 를 취해서 넣고, EDTA $50 \mu \mathrm{L}$, phenol-nitroprusside $200 \mu \mathrm{L}$ 와 $\mathrm{NaOH}$-hypochlorite $200 \mu \mathrm{L}$ 를 넣어 $50{ }^{\circ} \mathrm{C}$ 수조에서 30 분간 발 색시킨 후 $630 \mathrm{~nm}$ 에서 흡광도를 측정하였다. 암모니아 농도 및 urease 활성 저해도(\%) 계산은 jack bean과 Bacillus urease 활 성 계산방법과 동일하다.

\section{Jack bean urease 반웅속도에 미치는 목초액의 영향}

목초액의 요소분해 저해 기작을 알기 위하여 목초액 $500,5,000$, $10,000 \mathrm{mg} / \mathrm{L}$ 와 요소농도를 $20,80,160,320,500 \mathrm{mM}$ 로 달리 하여 $35^{\circ} \mathrm{C}$ 에서 3 분 동안 반응시킨 후 jack bean urease 반응 속도를 측정하였다. 요소농도별 반응속도값을 요소농도와 반응 속도의 역수를 취하여 Lineweaver-Burk plot으로 환산하여 $\operatorname{Vmax}, \mathrm{Km}$ 값을 구한 후 inhibition의 반응기작을 평가하였다.

\section{토양 내 요소 가수분해에 미치는 목초액의 영향}

목초액이 토양 내 요소 가수분해에 미치는 영향을 보기 위하여 요소와 목초액을 토양에 직접 처리한 후 요소 가수분해 시 발 생하는 토양 내 암모니아를 $2 \mathrm{M} \mathrm{KCl}$ 추출-indophenol blue 변법 으로 측정하여 요소 가수분해 정도로 나타내었다( $\operatorname{Lim}$ 등 1998, Keeney와 Nelson 1982). 음건 후 토양의 수분함량을 30\%로 맞 추고 $35^{\circ} \mathrm{C}$ 에서 하루 배양한 토양 $20 \mathrm{~g}$ 에 urea $100 \mathrm{mg}$ 과 목초 희석액을 증류잔사물 기준 농도별 $(1,000,5,000,10,000 \mathrm{mg} / \mathrm{L})$ 로 $1 \mathrm{~mL}$ 씩 첨가한 후 $35^{\circ} \mathrm{C}$ 항온 배양기에서 $1,2,3,5,10$ 일 동안 항온 배양하였다. 이때 토양의 수분함량은 미생물의 최적 수분함량인 water filled pore space $60 \%$ 로 맞추었다(Harris 1980). 배양 후 $20 \mathrm{~g}$ 토양 중 $2 \mathrm{~g}$ 을 취해 $2 \mathrm{M} \mathrm{KCl} 20 \mathrm{~mL}$ 를 넣어 30 분간 진탕 후 No. 2 여과지에 여과하였다. 증류수 $400 \mu \mathrm{L}$ 에 여과한 토양 추출액 $100 \mu \mathrm{L}$ 를 취해서 넣고, EDTA $50 \mu \mathrm{L}$, phenol-nitroprusside $200 \mu \mathrm{L}$ 와 $\mathrm{NaOH}$-hypochlorite $200 \mu \mathrm{L}$ 를 넣어 $50{ }^{\circ} \mathrm{C}$ 수조에서 30 분간 발색시킨 후 $630 \mathrm{~nm}$ 에서 흡광도 를 측정하였다. Control은 목초액 대신 $\mathrm{MeOH}$ 를 처리하는 것으 로 하였다.

\section{분석 데이터의 통계적 처리}

모든 실험은 3 반복으로 하였으며 분석한 데이터는 평균과 표 준편차로 표시하였다. 목초액 처리에 따른 urease 활성 저해는 $\mathrm{R}$ 3.3.3 프로그램을 이용하여 일원분산분석으로 차이를 검정하 였다. 사후검정으로 Tukey HSD를 사용하였으며 처리 집단에 차이가 없는 경우 $(p<0.05)$ 같은 영문자로 그래프 위에 표시하 였다.

\section{결과 및 고찰}

\section{목초액 및 토양 특성 분석}

본 실험에 사용된 목초원액의 평균 $\mathrm{pH}$ 는 3.1로 낮은 산도를 나 타냈다. 이는 목초액의 구성성분인 acetic acid, carboxylic acid 의 영향인 것으로 판단된다. 목초액의 $\mathrm{pH}$ 는 목초액을 만드는데 사용된 식물체에 따라 조금씩 다르게 나타나지만 주로 2.5 에서 3.5 의 $\mathrm{pH}$ 를 나타냈다(Mathew와 Zakaria 2015). 희석액 또한 100 배 희석액이 $\mathrm{pH} 3.3,1,000$ 배 희석액이 $\mathrm{pH} 3.9$ 로 희석을 해도 낮은 산도를 유지하는 특징을 보였다. 증류잔사물 분석 결 과 목초원액 $1 \mathrm{~L}$ 당 $15.5 \mathrm{~g}$ 의 증류잔사물을 함유하고 있었다. 껍 질을 제거한 자작나무의 목초액은 $74.4 \%$ 의 물과 $25.3 \%$ 의 유기 물을 포함하고 있는 것으로 보고되었다(Hagner 등, 2013). 목초 액의 구성 성분은 열분해 시 가열 시간, 온도, 원재료에 따라 다르게 나타나나 목초액은 주로 guaiacols, catechols, syringols, vanillins, isoeugenol, phenol, furans, pyrans, carboxaldehydes, hydroxyketones, sugars, methanol, acetic acid, carboxylic acid 로 구성되어 있다(Zulkarami 등, 2011; Mathew와 Zakaria 2015). 목초액의 총 질소 함량은 $0.15 \%$ 로 유기질 비료에 비해 서 낮은 편으로 비료적 가치는 없었다. 암모니움태 질소 $\left(\mathrm{NH}_{4}^{+}-\right.$ $\mathrm{N})$ 농도는 평균 $385 \mathrm{mg} / \mathrm{kg}$ 이었고 질산태 질소 $\left(\mathrm{NO}_{3}{ }^{-}-\mathrm{N}\right)$ 는 검출 되지 않았다. 실험에 사용된 토양의 물리화학적 특성은 Table 1 에 나타나 있으며 일반적인 시설재배지 토양의 특징을 보이고 있었다.

\section{목초액이 다양한 urease 활성에 미치는 영향}

목초액의 처리는 목초액을 처리하지 않은 control에 비해 식물 urease 중 하나인 jack bean urease 활성에 저해효과를 나타냈다 (Fig. 1A). 목초액 $10,000 \mathrm{mg} / \mathrm{L}$ 처리시 control에 비해 약 $83 \%$ 의 요소가수분해 저해효과를 보였으며, $1,000 \mathrm{mg} / \mathrm{L}$ 처리에서는 약 $38 \%$ 의 저해효과를 보였으나 $100 \mathrm{mg} / \mathrm{L}$ 처리에서는 약 $11 \%$ 저해 로 요소분해 억제효과를 거의 보이지 않았다. 목초액이 jack bean urease에 대한 저해 효과를 설명하기 위하여 Lineweaber-Burk 그 래프를 그려 평가하였다(Fig. 2). 다양한 농도로 목초액을 처리했 을 때 $\mathrm{V}_{\max }$ 와 $\mathrm{K}_{\mathrm{m}}$ 값을 계산하여 Table 2에 나타내었다. Lineweaber-Burk 그래프로부터 평가한 결과 jeackbean urease에 대한 저해는 non-competitive inhibition으로 판단된다.

목초액을 처리하였을 때 Bacillus pasteurii urease 활성 역시 저해되는 효과를 보였으며, $10,000 \mathrm{mg} / \mathrm{L}$ 처리시 무처리에 비해 약 $90 \%$ 정도의 저해효과를 보였다. $1,000 \mathrm{mg} / \mathrm{L}$ 처리에서는 약 $55 \%$ 의 저해효과를 보였으나 $100 \mathrm{mg} / \mathrm{L}$ 처리에서는 약 $15 \%$ 저 해로 jack bean urease 활성 결과와 마찬가지로 요소분해 억제 효과를 거의 보이지 않았다(Fig. 1B).

Table 1 Physicochemical properties of the upland soil

\begin{tabular}{cccccc}
\hline $\mathrm{pH}(1: 5)$ & $\mathrm{EC}(\mathrm{dS} / \mathrm{m}, 1: 5)$ & Organic matter $(\%)$ & Total nitrogen $(\mathrm{mg} / \mathrm{g})$ & $\mathrm{C} / \mathrm{N}$ ratio & Available $\mathrm{P}_{2} \mathrm{O}_{5}(\mathrm{mg} / \mathrm{kg})$ \\
\hline 6.20 & 1.13 & 1.60 & 1.20 & 13.30 & 546 \\
\hline \multirow{2}{*}{$\mathrm{CEC}(\mathrm{cmol} / \mathrm{kg})$} & \multicolumn{2}{c}{$\mathrm{EC}(\mathrm{cmol} / \mathrm{kg})$} & $\mathrm{N}$ & Soil texture \\
\cline { 2 - 7 } & $\mathrm{Ca}$ & $\mathrm{Mg}$ & $\mathrm{K}$ & $\mathrm{Na}$ & Sandy loam \\
\hline 12.3 & 9.10 & 3.10 & 0.44 & 0.35 & \\
\hline
\end{tabular}




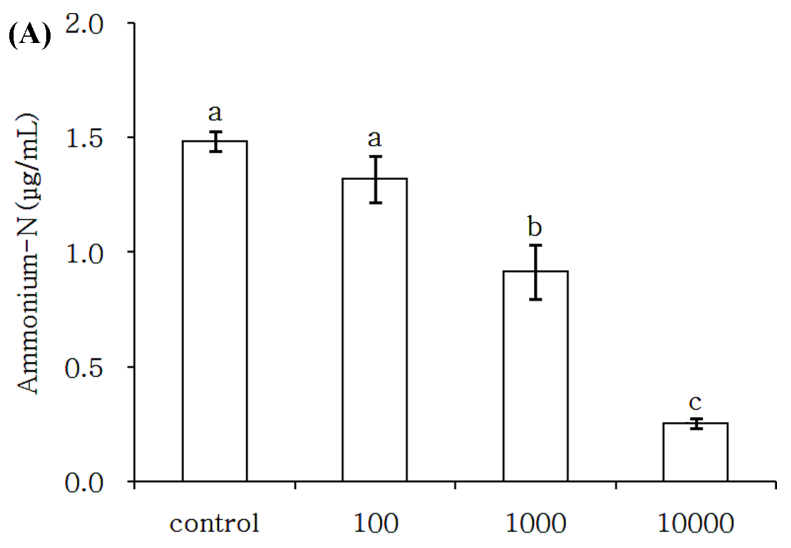

Pyroligneous acid concentrations (mg/L)

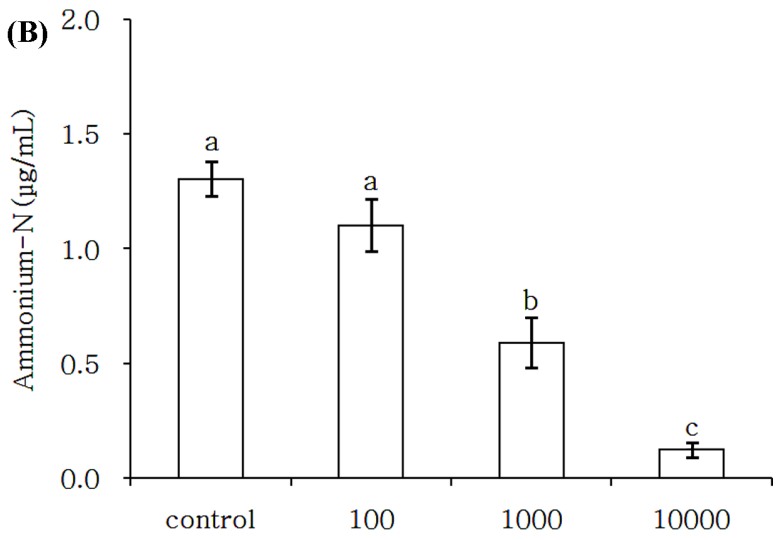

Pyroligneous acid concentrations (mg/L)

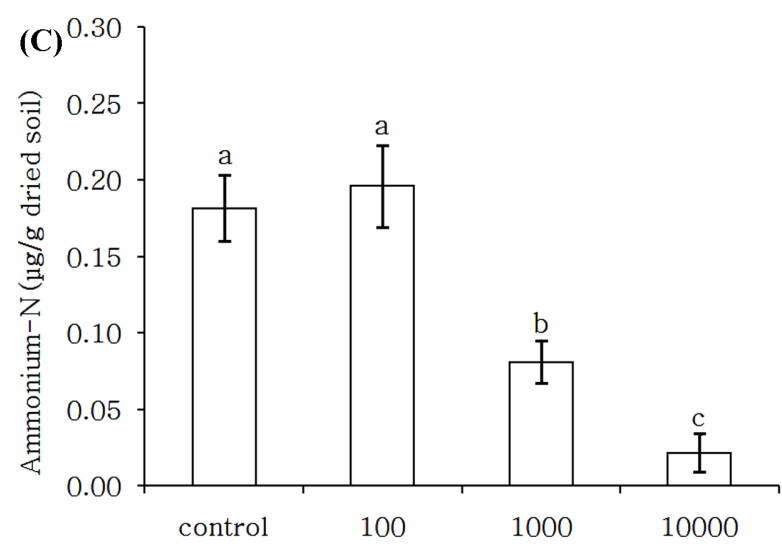

Pyroligneous acid concentrations (mg/L)

Fig. 1 Effects of pyroligneous acids on activity of Jack bean urease (A), Bacillus pasteurii urease (B) and soil urease (C). Data are expressed as mean \pm standard deviation. Means with the same letter are not significantly different $(p<0.05)$

토양 urease는 목초액 $10,000 \mathrm{mg} / \mathrm{L}$ 를 처리하였을 경우 무처 리에 비해 약 $88 \%$ 정도의 저해효과를 보였으며 $1,000 \mathrm{mg} / \mathrm{L}$ 처 리시 약 $55 \%$ 정도의 저해효과를 보였다. $100 \mathrm{mg} / \mathrm{L}$ 처리의 경 우 $-8 \%$ 로 오히려 활성이 증가하였으나, 오차범위 내에서 control 과 유의차는 없었다(Fig. 1C). 토양 urease 활성 저해효과 또한
Table $2 \mathrm{~V}_{\max }$ and $\mathrm{K}_{\mathrm{m}}$ values calculated from Lineweaver-Burk plot

\begin{tabular}{ccc}
\hline $\begin{array}{c}\text { Pyroligneous acid } \\
\text { concentrations }\end{array}$ & $\mathrm{V}_{\max }\left(\mathrm{mg} / \mathrm{L} \mathrm{NH}_{4}^{+} / \mathrm{min}\right)$ & $\mathrm{K}_{\mathrm{m}}(\mathrm{mM})$ \\
\hline Control & 2.93 & 448 \\
$500 \mathrm{mg} / \mathrm{L}$ & 2.94 & 501 \\
$5000 \mathrm{mg} / \mathrm{L}$ & 0.68 & 133 \\
$10000 \mathrm{mg} / \mathrm{L}$ & 0.45 & 100 \\
\hline
\end{tabular}

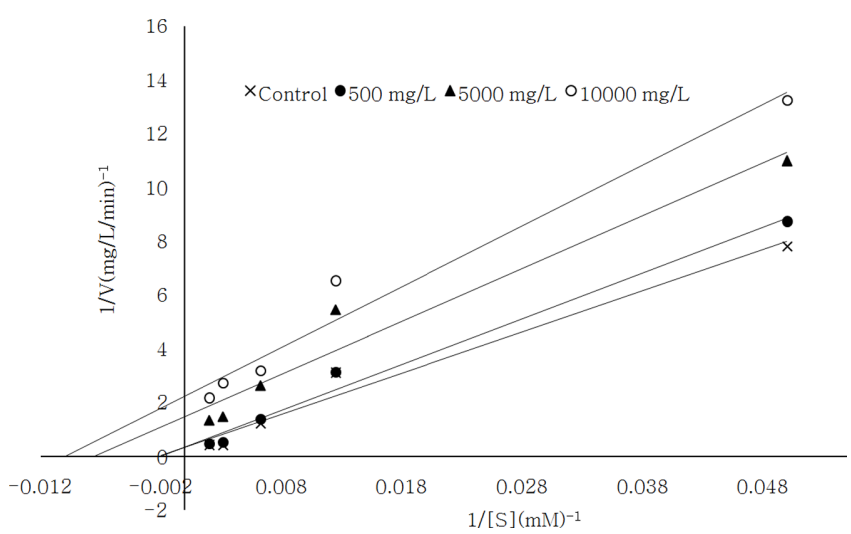

Fig. 2 Lineweaver-Burk plot of urease inhibition at different pyroligneous acid concentrations. control $(\times) ; 500 \mathrm{mg} / \mathrm{L}$ pyroligneous acids $(\mathbf{O})$; $5000 \mathrm{mg} / \mathrm{L}$ pyroligneous acids $(\mathbf{\Delta}) ; 10000 \mathrm{mg} / \mathrm{L}$ pyroligneous acids $(\bigcirc)$

jack bean과 Bacillus urease 활성 저해효과와 동일한 경향을 보 였다. 토양에는 식물과 미생물 유래 urease 뿐만 아니라 토양 내 점토광물과 결합하여 점토광물-urease complex가 존재하기 때문에 토양 urease에 저해효과를 보였다는 것은 목초액이 친 환경 urease inhibitor로서 가치가 있다는 것을 의미한다.

이러한 실험결과는 유기농업용 목초액의 비료적 가치 연구(김 등, 2000)와 동일한 경향의 결과였고, 이로서 목초액의 urease 억제효과를 재차 검증할 수 있었다. 하지만 과거 연구에서는 Kjeldahl 증류법을 이용하였기 때문에 저해효과를 규명하는데 많 은 시간과 노력이 소모되어 목초액 내 요소분해 억제효과를 가 지는 특정성분을 찾는데 많은 제약이 따랐으나, 이번 연구에서 도입한 indophenol blue법은 시간당 1,000 개 이상의 시료를 분 석할 수 있어 목초액 내 urease 저해효과를 갖는 성분을 탐색 하는데 많은 도움이 될 것으로 판단된다. 이와 비슷한 연구로 목초액을 질소 비료와 함께 벼에 처리했을 때 질소 이용 효율 이 높아졌다는 보고가 있었으며(Jianming 2003), 목초액의 사 용은 토양의 잔류상 질소 함량에 영향을 미쳐 작물의 영양분 이용도를 높일 수 있다는 발표를 하였다(Jeong 등, 2015). 목초 액과 biochar poultry manure compost를 같이 처리하여 urease 활성을 평가한 연구에서는 bulk 토양에서 urease 활성이 증가하 였으나 근권부 토양에서는 urease 활성에 큰 차이가 없는 것으 로 나타났다( $\mathrm{Lu}$ 등, 2015). 그러나 상기 연구에서는 목초액만 따로 처리한 것이 아니라 토양 첨가제를 복합적으로 처리하였 기 때문에 본 연구와 그 결과를 비교하기는 어려웠다.

목초액과 구성 물질을 각각 처리하여 느타리버섯의 자실체 형성(fruiting ratio)을 평가한 연구에서는 목초액이 느타리버섯의 자실체 형성에 효과적이었으며 여러 구성 화합물을 평가한 결 


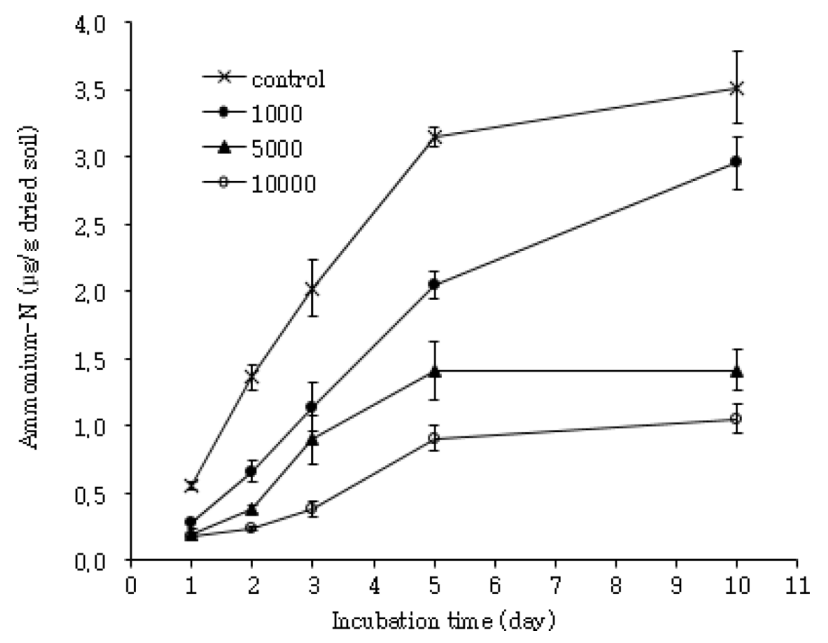

Fig. 3 Effects of pyroligneous acids on soil urea hydolysis. control $(\times)$; $1,000 \mathrm{mg} / \mathrm{L}$ pyroligneous acids $(\mathbf{O}) ; 5,000 \mathrm{mg} / \mathrm{L}$ pyroligneous acids $(\mathbf{\Delta})$; $10,000 \mathrm{mg} / \mathrm{L}$ pyroligneous acids $(\mathrm{O})$

과 2-methoxyphenol이 가장 효과가 높은 것을 확인하였다 (Yoshimura 등, 1995). 그러나 생육이 증대된 메커니즘에 대해 서는 구체적으로 설명하지 않았다. 또한 한국 토종 닭에 목초 액을 식이요법으로 $0.2 \%$ 주었을 때 암모니아 가스 농도가 처 리하지 않은 경우에 비해 현저히 감소되었으며 혈청에 총 단백 질 함량이 높아졌다는 보고(Shim 등, 2010)가 있어 목초액이 urease 활성을 저해한 것으로 판단된다.

\section{토양 내 요소 가수분해에 미치는 목초액의 영향}

목초액과 요소를 토양에 처리하고 10 일 경과 후 $10,000,5,000$ $\mathrm{mg} / \mathrm{L}$ 목초액을 처리하였을 경우 각각 약 70 과 $60 \%$ 의 요소가 수분해 저해효과를 보였으며, $1,000 \mathrm{mg} / \mathrm{L}$ 목초액을 처리하였을 때는 $16 \%$ 의 요소가수분해 저해효과를 보였다. 이는 목초액의 증류잔사물 기준 $5,000 \mathrm{mg} / \mathrm{L}$ 를 $1 \mathrm{~mL}$ 처리하였으므로 요소 100 $\mathrm{mg}$ 대비 $5 \mathrm{mg}$ 즉 요소비료 중량의 $5 \%$ 를 처리하였을 때 $60 \%$ 의 저해효과를 보였다(Fig. 3)

이전 연구에서 논토양에 혐기적으로 소화시킨 우분을 비료로 공급했을 때 목초액을 함께 처리하면 토양의 $\mathrm{pH}$ 를 7.8 에서 6.0 으로 산성화시키면서 암모니아의 휘산을 효과적으로 억제하는 것으로 보고하였다(Win 등, 2009). 이들은 토양의 $\mathrm{pH}$ 저하가 암모니아의 휘산을 억제한다고 평가하였으나 본 연구 결과에 따 르면 $\mathrm{pH}$ 의 저하 뿐만아니라 토양 내 urease 활성 저해가 암모 니아의 휘산에 영향을 미친 것으로 판단된다. 목초액에 의한 요 소의 가수분해 저해효과로 목초액을 요소 비료와 함께 토양에 처리했을 때 암모니아의 휘산을 막아 요소 비료의 시비 효율을 높일 수 있다는 결론을 내릴 수 있었다. 따라서 목초액을 요소 비료와 사용하면 천연 물질로 환경에 해를 미치지 않으면서 부 작용 없이 질소의 완효적 공급이 가능할 것으로 판단된다.

\section{초 록}

본 연구는 요소비료를 처리할 때 가수분해가 일어나 암모니아
로 휘산되어 손실되는 것을 억제하기 위한 목적으로 목초액이 요소분해에 미치는 영향을 규명하고자 하였다. 기존에 수많은 요소분해 합성억제제들이 개발 또는 탐색되어 왔으나, 토양 또 는 환경 별로 효과가 일정치 않고 합성물질의 경우 환경에 미 치는 영향을 고려해야 한다는 점 등 때문에 그 사용이 제한되 고 있는 실정이다. 본 연구에서는 친환경 농업자재인 목초액이 토양 중 요소분해에 미치는 영향을 요소분해효소(urease)활성 억 제효과를 통해 평가하였다. 목초액은 식물 urease와 미생물 urease 활성저해 효과뿐만 아니라 다양한 urease complex가 존 재하는 토양 urease에도 저해효과를 보였다. 이러한 요소분해효 소의 저해는 jack bean urease 반응속도를 측정한 결과 noncompetitive inhibition으로 판단된다. 또한 목초액을 요소와 함 께 토양에 처리하였을 경우 토양 내 요소분해작용을 억제하였 다. 이를 통해 목초액을 요소 비료와 같이 처리할 경우 식물에 공급되는 질소의 효율을 증진시킴과 동시에 토양에 공급되는 질 소비료의 총량을 절감하여 친환경 농업에 도움이 될 것으로 판 단된다.

Keywords 목초액 · 비경쟁적 저해 · 요소 가수분해 · 요소가수 분해 효소 · 토양

감사의글 실험의 아이디어를 주시고 지도편달해주신 고 임선욱 선생님께 감사드립니다.

\section{References}

Bai J, Xu H, Xiao R, Gao H, Zhang K, Ding Q (2014) Path Analysis for Soil Urease Activities and Nutrient Contents in a Mountain Valley Wetland, China. CLEAN-Soil Air Water 42: 324-330

Bray RH, Kurtz LT (1945) Determination of total, organic, and available forms of phosphorus in soils. Soil Sci 59: 39-45

Bremner JM, Keeney DR (1965) Steam distillation methods for determination of ammonium, nitrate and nitrite. Anal Chim Acta 32: 485-495

Bremner JM, Mulvaney CS (1982) Nitrogen-total. In: Page AL, Miller RH, Keeney DR (ed) Methods of soil analysis, part 2: chemical and microbiological properties, 2nd edn. American Society of Agronomy, Madison, pp. 595-624

Byrnes BH, Freney JR (1995) Recent developments on the use of urease inhibitors in the tropics. Fertil Res 42: 251-259

Dominguez MJ, Sanmartin C, Font M, Palop JA, San Francisco S, Urrutia O, Houdusse F, Garcia-Mina J (2008) Design, synthesis, and biological evaluation of phosphoramide derivatives as urease inhibitors. J Agric Food Chem 56: 3721-3731

Green AJ (1981) Particle-size analysis. In: Mckeague JA (ed) Manual on soil sampling and method of analysis. Canadian Society of Soil Science, Ottawa, pp 545-567

Hagner M, Penttinen OP, Tiilikkala K, Setala H (2013) The effects of biochar, wood vinegar and plants on glyphosate leaching and degradation. Eur J Soil Biol 58: 1-7

Harris RF (1980) Effect of water potential on microbial growth and activity. SSSA, Madison

Jeong KW, Kim BS, Ultra Jr VU, Lee SC (2015) Effects of rhizosphere microorganisms and wood vinegar mixtures on rice growth and soil properties. Korean J Crop Sci 60: 355-365

Jianming Z (2003) Effect of the solution of wood vinegar on yield and nitrogen-utilization of rice. J Anhui Agric Sci 31: 542-543

Keeney DR, Nelson DW (1982) Nitrogen inorganic forms. In: Page Al (ed) Methods of soil analysis. Part 2. 2nd ed. Agronomy 9. ASA and SSSA, 
Madison, pp 643-698

Kim MK, Park HJ, Lim SU (2000) Study on the value of pyroligneous acids as organic fertilizer, Daesan Nonchong 8: 279-295

Kiss S, Simihaian M (2013) Improving efficiency of urea fertilizers by inhibition of soil urease activity. Springer Science \& Business Media, Netherlands

Krajewska B, Zaborska W (2007) Jack bean urease: The effect of active-site binding inhibitors on the reactivity of enzyme thiol groups. Bioorg Chem 35: $355-365$

Lim SU (1996) Development of new fertilizer for 2000s, Korean Society of Soil Science and Fertilizer Symposium 5-38

Lim SU, Shin MH, Park HJ, Kim MK (1998) Inhibition of urea hydrolysis and nitrification in upland soils by Artemisia asiatica extracts. Korean J Soil Sci Fertil 31: 392-399

Lu H, Lashari MS, Liu X, Ji H, Li L, Zheng J, Kibue GW, Joseph S, Pan G (2015) Changes in soil microbial community structure and enzyme activity with amendment of biochar-manure compost and pyroligneous solution in a saline soil from Central China. Eur J Soil Biol 70: 67-76

Mathew S, Zakaria ZA (2015) Pyroligneous acid-the smoky acidic liquid from plant biomass. App Microbial Biotechnol 99: 611-622

McKenzie RH, Middleton AB, Pfiffner PG, Bremer E (2010) Evaluation of polymer-coated urea and urease inhibitor for winter wheat in southern Alberta. Agron J 102: 1210-1216

McLean EO (1982) Soil pH and lime requirement. In: Page AL (ed) Methods of soil analysis. Part2. Chemical and microbiological properties. 2nd ed. Agronomy 9, ASA and SSSA, Madison, pp 199-209

Mobley HL, Hausinger RP (1989) Microbial urease; significance, regulation and molecular characterization. Microbiol Rev 53: 85-108

Pan B, Lam SK, Mosier A, Luo Y, Chen D (2016) Ammonia volatilization from synthetic fertilizers and its mitigation strategies: A global synthesis.
Agric Ecosyst Environ, 232: 283-289

Reeuwijk LP van (2002) Procedures for Soil Analysis. 6th ed. International Soil Reference and Information Centre, Wageningen, Netherlands

Rhoades JD (1982) Cation exchange capacity. In: Page AL (ed) Methods of soil analysis. Part2. Chemical and microbiological properties. 2nd ed. Agronomy 9. ASA and SSSA, Madison, pp 199-209

Shaviv A (2001) Advances in controlled-release fertilizers. Adv Agron 71: 149

Shim KS, Ji JR, Na CS, Park JH (2010) Effect of pyroligneous acid supplementation on growth performance, blood parameter, ammonia gas emission and fatty acid composition of breast meat in Korean native chicken. Korean J Poult Sci 37: 207-213

Tabatabai MA, Bremner JM (1972) Assay of urease activity in soils. Soil Biol Biochem 4: 479-487

Win KT, Toyota K, Motobayashi T, Hosomi M (2009) Suppression of ammonia volatilization from a paddy soil fertilized with anaerobically digested cattle slurry by wood vinegar application and floodwater management. Soil Sci Plant Nutr 55: 190-202

Xu X, Zhou L, Van Cleemput O, Wang Z (2000) Fate of urea-15N in a soilwheat system as influenced by urease inhibitor hydroquinone and nitrification inhibitor dicyandiamide. Plant Soil 220: 261-270

Yoshimura H, Washio H, Yoshida S, Seino T, Otaka M, Matsubara K, Matsubara M (1995) Promoting effect of wood vinegar compounds on fruit-body formation of Pleurotus ostreatus. Mycoscience 36: 173-177

Zaborska W, Kot M, Superata K (2002) Inhibition of jack bean urease by 1,4benzoquinone and 2,5-dimethyl-1,4-benzoquinone. Evaluation of the inhibition mechanism. J Enzyme Inhib Med Chem 17: 247-253

Zulkarami B, Ashrafuzzaman M, Husni MO, Ismail MR (2011) Effect of pyroligneous acid on growth, yield and quality improvement of rockmelon in soilless culture. Australian J Crop Sci 5: 1508-1514 